\section{Scientific journal}

PHYSICAL AND MATHEMATICAL EDUCATION

Has been issued since 2013.

Науковий журнал

ФІЗИКО-МАТЕМАТИЧНА ОСВІТА

Видається з 2013.
ISSN 2413-158X (online)

ISSN 2413-1571 (print)

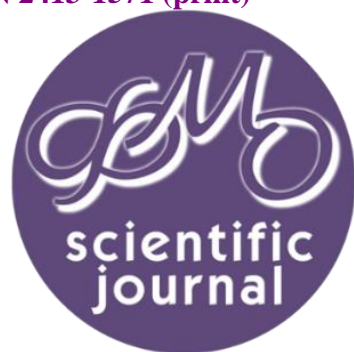

Гайда В.Я. Організація педагогічного експерименту з упровадження методичної системи формування самоосвітньої компетентності учнів основної школи на засадах сталого розвитку. Фізико-математична освіта, 2021. Випуск 5(31). С. 23-27.

Gaida V. Organization of pedagogical experiment on implementation of methodological system of formation of selfeducational competence of competence. Physical and Mathematical Education, 2021. Issue 5(31). P. 23-27.

DOI 10.31110/2413-1571-2021-031-5-004

Удк 373.51

В.я. Гайда

Центральноукраїнський державний педагогічний університет імені Володимира Винниченка, Україна gaidavasil@gmail.com

https://orcid.org/0000-0003-3077-2311

\title{
ОРГАНІЗАЦІЯ ПЕДАГОГІЧНОГО ЕКСПЕРИМЕНТУ \\ З УПРОВАДЖЕННЯ МЕТОДИЧНОЇ СИСТЕМИ ФОРМУВАННЯ САМООСВІТНЬОЇ КОМПЕТЕНТНОСТІ УЧНІВ ОСНОВНОЇ ШКОЛИ НА ЗАСАДАХ СТАЛОГО РОЗВИТКУ
}

\section{АНОТАЦІЯ}

Формулювання проблеми. У статті висвітлені результати здійсненого педагогічного експерименту з упровадження розробленої методичної системи формування самоосвітньої компетентності учнів основної школи в процесі вивчення фізики на засадах сталого розвитку. При дотриманні принципів системного підходу до аналізу й організації освітнього процесу формування самоосвітньої компетентності учнів основної иколи в освітньому процесі з фізики, повноцінному дотриманні педагогічних умов його реалізації та забезпеченні комплексом ефективних форм, методів, засобів та технологій в освітньому процесі, передбачаємо сформованість високого рівня самоосвітньої компетентності учнів $33 \mathrm{CO}$.

Матеріали і методи. Під час реалізації педагогічного експерименту послуговувалися теоретичними (аналіз науково-методичної літератури з питань формування самоосвітньої компетентності учнів), емпіричними (спостереження, анкетування, тестування), а також статистичними методами опрацюванню результатів дослідження (критерій Пірсона та Стьюдента). Проведено педагогічний експеримент (констатувальний, пошуковий, формувальний та підсумковий етапи) до якого було залучено 1227 учнів із 24 закладів освіти Тернопільської (18), Волинської (3) та Кіровоградської (3) областей.

Результати. Результати педагогічного експерименту підтвердили статистичну достовірність впливу запропонованої методичної системи на якісні показники самоосвітніх умінь та позитивні зрушення у засвоєнні учнями навчального матеріалу з фізики.

Висновки. Впровадження розробленої методичної системи сприяє: підвищенню мотивації учнів до самоосвіти, зацікавленості до вивчення фізики, розвитку критичного мислення, удосконаленню вмінь учнів використовувати хмарні сервіси для виконання особистісних і сочіально значущих завдань та навчальних проєктів, розвитку вмінь використовувати у прочесі вивчення фізики прикладне програмне забезпечення, виробленню навичок самостійності, роботи в групі, навчальної комунікації тощо.

КлЮчОВІ СЛОвА: самоосвітня компетентність, навчання фізики, педагогічний експеримент, сталий розвиток, учні основної школи, формування самоосвітньої компетентності учнів основної иколи.

\section{ВСТУП}

Постановка проблеми. Інформаційне суспільство потребує молоді, здатної до саморозвитку та самонавчання в умовах загострення глобальної екологічної кризи, інертності освіти та переходу на засади сталого розвитку, що $\epsilon$ найперспективнішою ідеологією третього тисячоліття і поєднує три важливі елементи суспільного розвитку: екологічний, економічний та соціальний. Освіта повинна нести випереджувальний характер, відповідати основним тенденціям розвитку суспільства, допомагати молоді швидко адаптовуватися до умов цифрового суспільства. Тому постає проблема формування самоосвітньої компетентності як здатності навчатися впродовж життя в умовах закладів освіти загалом, а також у процесі навчання фізики, зокрема.

(c) В.Я. Гайда, 2021. 
Актуальність дослідження. Проблему вдосконалення методики навчання фізики досліджували: П.С. Атаманчук, О.І. Бугайов, С.П. Величко, С.У. Гончаренко, Є.В. Коршак, Н.В. Подопригора, М.І. Садовий, В.П. Сергієнко, О.М. Трифонова та ін. Враховуючи тривале вивчення проблеми дослідження (Гайда, 2019; Гайда, 2020) та на основі вивчення досвіду роботи учителів фізики Тернопільської області, ми дійшли до висновку, що проблема формування самоосвітньої компетентності учнів основної школи на засадах сталого розвитку потребує детального вивчення, розробки відповідного методичного супроводу та проведення педагогічного експерименту з перевірки ефективності такої методичної системи.

Мета статті полягає у висвітлені особливостей організації, проведення та аналізу результатів педагогічного експерименту щодо упровадження методичної системи формування самоосвітньої компетентності учнів основної школи в освітньому процесі з фізики на засадах сталого розвитку.

\section{МЕТОДИ ДОСЛІДЖЕННЯ}

Для досягнення поставленої мети були використані теоретичні та емпіричні методи дослідження: аналіз психолого-педагогічної та науково-методичної літератури. Також були використані методи: спостереження за освітнім процесом; анкетування - для виявлення проблем у вивченні; тестування - на етапі діагностики знань учнів перед початком впровадження нововведень та на етапі визначення педагогічної ефективності; експеримент - 3 метою перевірки ефективності запровадженої методичної системи формування самоосвітньої компетентності учнів основної школи; статистичні методи - для опрацювання результатів дослідження.

\section{РЕЗУЛЬТАТИ ТА ЇХ ОБГОВОРЕННЯ}

За результатами науково-методичних розвідок поняття самоосвітня компетентність учня закладів загальної середньої освіти тлумачиться нами як інтегрована якість особистості, що визначається чіткими мотивами діяльності, зацікавленості в якісній самостійній діяльності, прагненням до самовдосконалення, певним чином організованими і систематизованими знаннями, самоосвітніми уміннями та рефлексивними навичками, спрямованістю на здобуття освіти впродовж життя, що дозволять успішно вирішувати питання самореалізації та саморозвитку. У структурі самоосвітньої компетентності виокремлено мотиваційно-ціннісний, когнітивний, організаційно-діяльнісний та рефлексивноаналітичний компоненти. Методика формування самоосвітньої компетентності учнів основної школи в освітньому процесі з фізики на засадах сталого розвитку базувалась на тлумаченні та дотриманні педагогічних умов. Педагогічними умовами формування самоосвітньої компетентності учнів основної школи в освітньому процесі з фізики на засадах сталого розвитку визначені: готовність вчителів до організації та реалізації процесу формування самоосвітньої компетентності учнів основної школи у процесі вивчення фізики на засадах сталого розвитку; здатність вчителів до формування мотиваційноціннісного ставлення учнів до самоосвітньої діяльності; наявність матеріально-технічного забезпечення кабінетів фізики; моніторинг рівня самоосвітніх умінь учнів.

Для комплексного вивчення педагогічного явища та перевірки ефективності методичної системи формування самоосвітньої компетентності учнів основної школи в освітньому процесі вивчення фізики на засадах сталого розвитку, ми опиралися на праці С.У. Гончаренка (Гончаренко, 2008) та Ю.К. Бабанського (Бабанский, 1985), у яких висвітлено основні вимоги до проведення педагогічного дослідження.

Педагогічний експеримент проводився впродовж 2018 - 2021 років.

На констатувальному етапі дослідження (2018 - 2019) вивчалися теоретичні засади та практичні напрацювання щодо проблеми формування самоосвітньої компетентності учнів основної школи під час вивчення фізики на засадах сталого розвитку (нормативні документи, які регламентують організацію освітнього процесу з фізики, з метою виявлення потенційної можливості формування самоосвітньої компетентності учнів основної школи на засадах сталого розвитку; навчально-методичнн забезпечення викладання фізики в основній школі; поняттєвий апарат дослідження; стан сформованості самоосвітньої компетентності учнів основної школи та готовність учителів здійснювати формування самоосвітньої компетентності учнів на засадах сталого розвитку).

В ході дослідження було з'ясовано, що проблема формування самоосвітньої компетентності учнів основної школи в освітньому процесі на засадах сталого розвитку в цілому не розв'язана (Гайда, 2020), тому запропоновано кроки щодо вирішення цієї проблеми. При цьому особливу увагу приділено соціокультурним, природнім та педагогічним чинникам, які сприяли / гальмували цей процес, впливаючи на мотивацію, ціннісні орієнтації учнів тощо.

В ході формувального етапу дослідження (2019 - 2020) схарактеризовано методику формування самоосвітньої компетентності учнів основної школи в освітньому процесі на засадах сталого розвитку та обґрунтовано педагогічні умови ефективності її впровадження в освітній процес. Запровадження в освітній процес ідей сталого розвитку полягало в: інтегруванні ідей сталого розвитку у зміст навчального матеріалу; поширенні позитивного досвіду в освіті, що сприятиме змінам у поведінці на користь сталості; сприянні розуміння сутності глобальних, національних і місцевих екологічних проблем з акцентом на їх соціально-економічні наслідки; впровадження нових підходів у навчанні, заохочування самоосвіти. Формування самоосвітньої компетентності учнів передбачало виконання вправ та задач, проведення дослідів та здійснення спостережень, реалізацію дослідницьких навчальних проєктів, ситуаційних вправ.

На підсумковому етапі педагогічного експерименту (2020 - 2021) здійснено перевірку ефективності методичної системи формування самоосвітньої компетентності учнів основної школи на засадах сталого розвитку через проведення педагогічного експерименту. Були сформовані контрольні та експериментальні класи; здійснено методичну підготовку учителів фізики до впровадження розробленої методичної системи в освітній процес; залучення до роботи творчої групи вчителів фізики з проблеми «Методичний супровід та діагностика якості сформованості самоосвітньої компетентності учнів закладів загальної середньої освіти»; організовувалися он-лайн лекції, тренінги, консультації з питань впровадження методичної системи; проведено контрольний зріз; проаналізовані кількісні результати Учителі, які брали участь в експерименті, забезпечувалися відповідними дидактичними матеріалами (https://ternofizik.blogspot.com/p/blogpage_12.html). 
У рамках дослідження відстежувалася динаміка процесу набуття учнями основної школи самоосвітніх знань та умінь, зокрема: цілеспрямованість, потреба в самовдосконаленні, ціннісні орієнтації, уміння планувати пізнавальну діяльність, інтелектуальні уміння, здатність орієнтуватися в інформаційних потоках, навички самоконтролю самоосвітньої діяльності, рефлексія, самостійність, комунікативні якості тощо.

На констатувальному етапі експерименту були залучені 801 учень 7 класу, 802 учні 8 класу, 852 учні 9 класу та 28 учителів фізики, які викладають в обраних для експерименту класах. Обсяг вибірки був достатнім, оскільки в основі добору вибірок лежала методика П. М. Воловика (Воловик, 1969), згідно з якою мінімальна кількість учасників експерименту вираховувалася за формулою:

$$
n=\frac{t^{2} p q}{\varepsilon^{2}}
$$

де $n$ - обсяг вибірки, $t$ - коефіцієнт Стьюдента, $p$ і $q$ - ймовірність правильних і неправильних відповідей, $\varepsilon-$ гранично допустима похибка, яка забезпечує рівень достовірності $P=0,95$. Тоді за таблицями критичне значення коефіцієнта $t=1,96$. За таких умов $p=q=0,5$ і $n$ буде становити 384 респонденти (Воловик, 1969).

3 метою виявлення рівня сформованості компонентів самоосвітньої компетентності учнів основної школи при вивченні фізики в рамках констатувального експерименту було проведено низку контрольних робіт, опитування, анкетування із застосуванням засобів дистанційного зв'язку (https://ternofizik.blogspot.com/).

Виявлено, що: 43 \% учнів зазвичай на уроках фізики працюють з великим напруженням, 44 \% опитаних не бачать сенсу в більшості завдань і вправ, які виконують в школі на уроках фізики, а 46 \% вважають, що в наш час не обов'язково добре знати фізику, 79 \% школярів стверджують, що є багато предметів, які цікавіше вивчати, ніж фізику, а 53 \% школярів дуже важко змусити себе вивчати фізику. На нашу думку це пов'язано із методами організації освітнього процесу учителями, які в основному використовують розв'язування задач, розповідь та бесіду, а школярі очікують побачити дивовижні та захоплюючі експерименти, активно досліджувати явища та виконувати завдання, пов'язані із довкіллям. Тому 25 \% учнів стверджують, що якби випала можливість, то вони навчалися б в іншій школі. Про те 62 \% учнів вважають, що людина повинна доводити свої вміння та навички до досконалості, 70 \% переконані, що самовиховання та самоосвіта повинні бути обов'язкові, якщо людина хоче досягти досконалості в чомусь, 67 \% прагнуть до найвищих результатів, виступаючи в будь-яких конкурсах чи змаганнях, 54 \% учнів стверджують, що якщо вони налаштовані до навчання, то роблять це краще, ніж інші, 65 \% вважають, щоб себе реалізувати в житті, всі предмети потрібно вивчати однаково добре, 49 \% думають, що люди, які добре знають фізику, у житті успішні та 35 \% впевнені, що добре знання з фізики надасть їм моральне задоволення і матеріальний достаток в житті. Для 89 \% учнів досягнення в навчанні не завжди однакові, а 40 \% школярів не доводять до кінця багато справ, за які беруться, хоча 91 \% стверджує, що якщо їм доводиться виконувати певне завдання, то намагаються робити це якомога краще.

Якість оволодіння певними навичками самоосвітньої діяльності (когнітивний та операційно-діяльнісний компоненти самоосвітньої компетентності) визначалися за допомогою коефіцієнта успішності засвоєння навички, як частки правильно виконаних суттєвих операцій певного рівня (Беспалько, 1989).

$$
K_{3}=\frac{1}{4 N} \sum_{i=1}^{4} n_{i} i
$$

де $K_{3}$ - коефіцієнт успішності засвоєння навички класом, $\mathrm{N}$ - загальна кількість учнів, $n_{i}-$ кількість учнів, що засвоїли навичку на рівні $i$, ( тут $i=1$ - початковий рівень, $i=2$ - середній, $i=3$ - достатній, $i=4$ - високий рівень).

Ми отримали наступні результати для коефіцієнта успішності засвоєння самоосвітніх умінь учнями 7-9 класів: здатність розкривати суть фізичних термінів на основі узагальнених планів становить близько 60 \%; працювати із текстом - 55 \%; працювати з опорними конспектами - 52 \%; виокремлювати структурно-логічні частини тексту - 53 \%; виокремлювати спільні - 54 \%;розрізняти певні об'єкти - $48 \%$; групувати та класифікувати - 65\%; користуватися пошуковими системами - 55 \%; аналізувати табличну інформацію - 53 \%; читати графічну інформацію - $56 \%$; розуміти схеми електричних кіл- 52 \%; встановлювати причинно-наслідкові зв'язки - 54 \%.

Коефіцієнт успішності засвоєння вміння розв'язувати задачі за малюнком сформований на рівні 54 \%; за графіком - 53 \%; за таблицею - 50 \%; задачі-оцінки - 49 \%. Коефіцієнт успішності засвоєння вміння планувати дослідження, визначати найкращі умови для його проведення сформовано на рівні 58 \%; обирати оптимальні умови спостережень $55 \%$; конструювати - 58 \%; аналізувати самоосвітню діяльність -51 \%; аналізувати результати здійсненого дослідження $52 \%$.

Формуючи завдання, зорієнтовані на формування і розвиток самоосвітньої компетентності учнів основної школи у процесі вивчення фізики на засадах сталого розвитку, ми інтегрували у зміст уроку фізики та зміст пропонованих завдань інформації, що пов'язана з проблемами навколишнього середовища, здоров'я людини, розвитку суспільства та можливими шляхами їх покращення, які сприяли здатності усвідомлено будувати свою навчальну діяльність залежно від форми пропонованої інформації, здійснювати контроль і самоконтроль результатів власної діяльності.

3 метою формування самоосвітніх умінь учнів нами були розроблені самостійно (Гайда, 2016) та запозичено із існуючої методичної та науково-популярної літератури різні типи навчальних завдань та інтерактивних вправ, орієнтованих на формування самоосвітньої компетентності учнів, зміст яких стосувався ідей сталого розвитку (https://ternofizik.blogspot.com/p/blog-page_10.html).

3 метою виявлення формувального впливу розробленої методики організації освітнього процесу на засадах сталого розвитку на рівні сформованості самоосвітньої компетентності учнів наприкінці експериментального навчання ми здійснили контрольний етап педагогічного експерименту. Дослідження здійснювали за ідентичними методиками, що застосовували на констатувальному етапі педагогічного експерименту.

Письмові роботи складались з двох варіантів контрольних і двох варіантів самостійних робіт, які були визначені в ході констатуючого експерименту (https://ternofizik.blogspot.com/p/blog-page_82.html). Контрольні зрізи проводилися наприкінці семестру. 
Узагальнюючи характерні відмінності у розподілах за рівнями сформованості мотиваційно-ціннісного, когнітивного, організаційно-діяльнісного та рефлексивно-аналітичного компонентів самоосвітньої компетентності учнів контрольних і експериментальних класів зазначимо, що в експериментальних класах по завершенню педагогічного експерименту засобами статистики доведено наявність позитивних змін у всіх компонентах самоосвітньої компетентності учнів основної школи (рис.1.). Варто відзначити, що в експериментальних класах суттєво зменшився відсоток учнів із початковим рівнем сформованості кожної із компонент самоосвітньої компетенції учнів, та зросла кількість учнів із високим рівнем сформованості цих компонент.

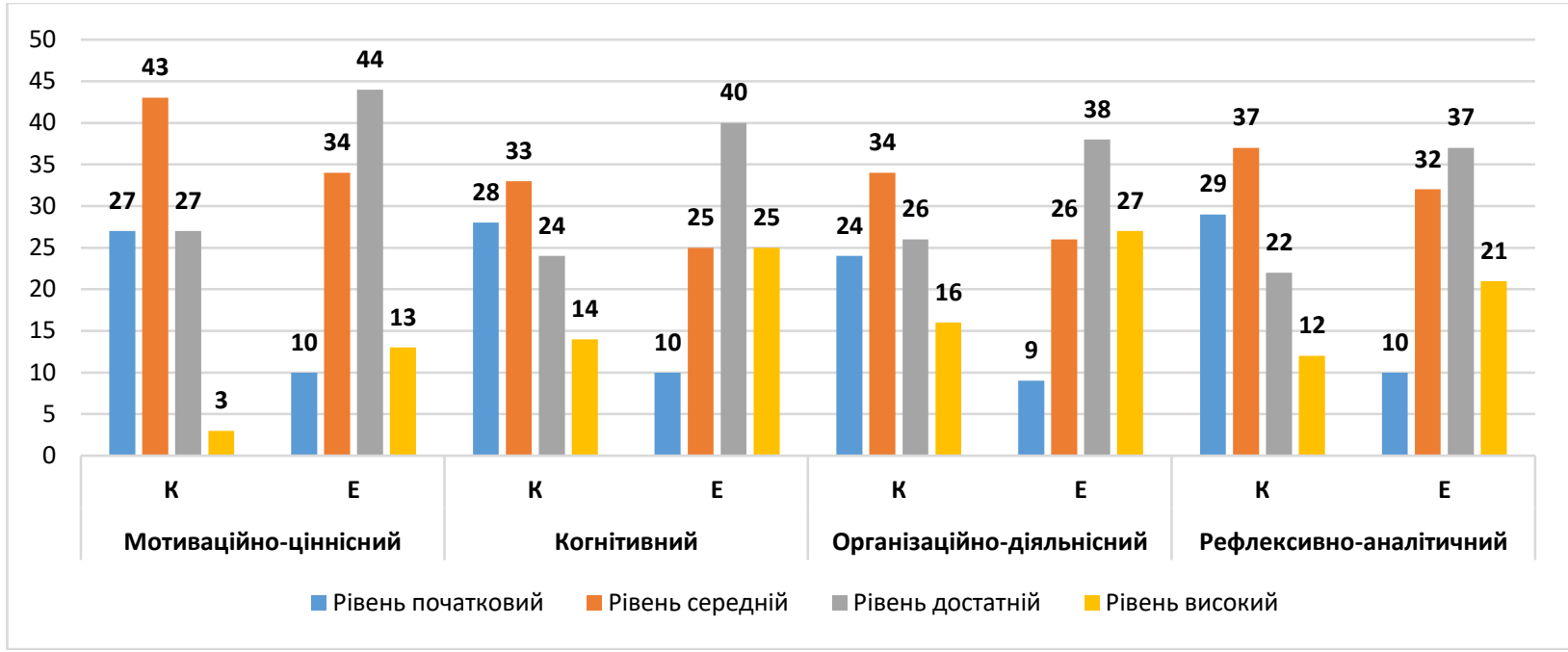

\section{Рис 1. Розподіл за рівнями сформованості компонентів самоосвітньої компетентності учнів контрольних $\mathbf{i}$ експериментальних класів.}

Спостережуване значення критерію $\chi^{2}$ спост для обраних нами вибірок становить 66,17, що значно більше критичного значення $\chi^{2}{ }_{\text {кр }}=7,81$. Здійснене порівняння вказує на суттєві відмінності між контрольними та експериментальними класами. Отримане значення критерію $Z_{c п}$ для вибірок становить 8,2, що значно більше критичного значення критерію за

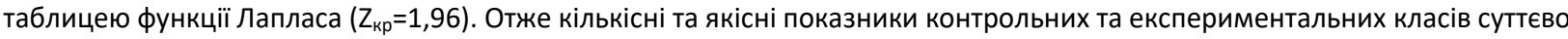
відрізняються.

\section{ВИСНОВКИ ТА ПЕРСПЕКТИВИ ПОДАЛЬШОГО ДОСЛІДЖЕННЯ}

У результаті проведеного педагогічного експерименту щодо формування самоосвітньої компетентності учнів основної школи в освітньому процесі вивчення фізики на засадах сталого розвитку встановлено: підвищення мотивації учнів до самоосвіти та ріст зацікавленості до вивчення фізики; розвиток логічного мислення та уміння учнів використовувати хмарні сервіси для виконання особистісних і соціально значущих завдань та навчальних проектів; сформованість навичок пошуку, отримання, опрацювання інформації для розв'язування навчальних та життєвих завдань; удосконалення уміння використовувати у процесі вивчення фізики прикладне програмне забезпечення; вироблення навичок самостійності, роботи в групі, навчальної комунікації тощо.

Отже, результати педагогічного експерименту дають підстави для висновку, що запропонована нами методична система формування самоосвітньої компетентності учнів основної у процесі вивчення фізики на засадах сталого розвитку $€$ продуктивною та може рекомендуватися до впровадження у практику навчання фізики у закладах загальної середньої освіти. Перспективи подальших досліджень полягають в удосконаленні методики формування когнітивного та організаційно-діяльнісного компонентів самоосвітньої компетентностей учнів; забезпеченні наступності в реалізації компетентнісного підходу до навчання фізики в основній школі; розробці методики формування самоосвітньої компетентності учнів старшої школи в освітньому процесі з фізики; створенні матеріально-технічного забезпечення реалізації процесу формування самоосвітньої компетентності учнів закладів загальної середньої освіти на засадах сталого розвитку.

\section{Список використаних джерел}

1. Бабанский Ю. К. Избранние педагогические труди. М. : Педагогика, 1989. 560 с.

2. Беспалько В.П. Основы теории педагогических систем. Воронеж: Издательство Воронежского университета, 1977. $304 \mathrm{c}$.

3. Воловик П.М. Теорія імовірності і математична статистика в педагогіці. К.: Рад. Школа, 1969.

4. Гайда В.Я. Модель процесу формування самоосвітньої компетентності учнів основної школи на уроках фізики. Фізикоматематична освіта. 2020. Випуск 3 (25). Частина 1. С. 38-43.

5. Гайда В.Я. Структура самоосвітньої компетентності учнів закладів загальної середньої освіти. Інноваційна педагогіка. Науковий журнал. Одеса: Причорноморський науково-дослідний інститут економіки та інновацій, 2019. Випуск 17. Том 2. С. 83-87.

6. Гайда В.Я. Фізика. Самостійні роботи. 7 клас. Кам'янець-Подільський : ФОП Сисин О.В., 2016. 44 с.

7. Гончаренко С. У. Педагогічні дослідження: Методологічні поради молодим науковцям. Київ-Вінниця: ДОВ „Вінниця”, 2008. 278 c. 


\section{References}

1. Babansky, Y. K. (1989). Selected pedagogical works. M .: Pedagogika. [in Russian]

2. Bespalko, V. P. (1989). Fundamentals of the theory of pedagogical systems. Voronezh: Voronezh University Press. [in Russian]

3. Volovik, P. M. (1989). Probability theory and mathematical statistics in pedagogy. K .: Rad. School. [in Ukrainian]

4. Gaida, V. Ya. (2020). Model of the process of formation of self-educational competence of primary school students in physics lessons. Physical and mathematical education. Issue 3 (25). Part 1. 38-43. [in Ukrainian]

5. Gaida, V.Ya. (2019). The structure of self-educational competence of students of general secondary education. Innovative pedagogy. Scientific journal. Odessa: Black Sea Research Institute of Economics and Innovation. Issue 17. Volume 2. 83-87. [in Ukrainian]

6. Gaida, V. Ya. (2016). Physics. Independent works. 7th grade. Kamyanets-Podilsky: FOP Sysyn OV. [in Ukrainian]

7. Goncharenko, S. V. (2008). Pedagogical research: Methodological advice to young scientists. Kyiv - Vinnytsia: DOV "Vinnytsia". [in Ukrainian]

\section{ORGANIZATION OF PEDAGOGICAL EXPERIMENT ON IMPLEMENTATION OF METHODOLOGICAL SYSTEM OF FORMATION OF SELF-EDUCATIONAL COMPETENCE OF COMPETENCE \\ Vasil Gaida}

Abstract.

Problem formulation. The article highlights the results of a pedagogical experiment on the implementation of the developed methodological system for the formation of self-educational competence of primary school students in the study of physics on the basis of sustainable development. In compliance with the principles of a systematic approach to the analysis and organization of the educational process of forming self-educational competence of primary school students in the educational process in physics, full compliance with pedagogical conditions of its implementation and providing a set of effective forms, methods, tools and technologies in the educational process, envisage the formation of a high level of self-educational competence of students of general secondary education institution.

Materials and methods. During the implementation of the pedagogical experiment we used theoretical (analysis of scientific and methodological literature on the formation of self-educational competence of students), empirical (observation, questionnaires, testing), as well as statistical methods of processing research results (Pearson and Student's test). A pedagogical experiment (ascertaining, searching, forming and final stages) was conducted, which involved 1227 students from 24 educational institutions of Ternopil (18), Volyn (3) and Kirovohrad (3) regions.

Results. The results of the pedagogical experiment confirmed the statistical significance of the influence of the proposed methodological system on the qualitative indicators of self-educational skills and positive changes in the assimilation of teaching material in physics by students.

Conclusions. The introduction of the developed methodological system contributes to: increasing students 'motivation for self-education, interest in studying physics, developing critical thinking, improving students' ability to use cloud services to perform personal and socially significant tasks and educational projects, developing skills to use application software in physics, independence skills, group work, educational communication, etc.

Key words: teaching physics, pedagogical experiment, self-educational competence, sustainable development, primary school students, formation of self-educational competence of primary school students. 